\title{
Getting our priorities in order: are our service values in line with the communities we serve?
}

\author{
Jocelyn S. Duffy \\ Portland State University, Portland, Oregon, USA \\ Damon E. Jaggars \\ University of Texas at Austin, Austin, Texas, USA, and \\ Shanna E. Smith \\ Columbia University, New York, New York, USA
}

\begin{abstract}
Purpose - LibQUAL $+{ }^{\circledR}$ allows users to rate their minimum, perceived, and desired levels of service for 22 items in three dimensions: information control, library as place, and service affect. Using the results from the 2005 survey at the University of Texas at Austin, this paper aims to examine how well the service priorities of library staff are aligned with the priorities of undergraduates, graduate students, and faculty.

Design/methodology/approach - The paper has re-scaled the "desired" score for each item to reflect the degree to which the item is above or below the average desired level for that individual. The rescaled scores (termed "priority" scores) for the 22 items were then compared between the four groups using a multivariate analysis of variance (MANOVA).

Findings - Preliminary results indicate that service priorities for library staff align more closely with those of undergraduates than with those of graduate students and faculty.

Practical implications - This analysis is a first step in identifying service priority gaps between library staff and the users they serve. The intention is to promote discussion among library staff about users' needs and how closely staff service priorities align with those needs. In addition, the findings may prove useful as management information by allowing the analysis of users' service priorities and integrating the results of this analysis into organizational decision making and planning processes.

Originality/value - This paper describes a development of LibQUAL $+\circledR$ that enables a greater depth of understanding of service priorities.
\end{abstract}

Keywords Customer service management, University libraries, Multivariate analysis,

Quality management

Paper type Research paper

\section{Introduction}

Academic libraries provide content and services core to the research, teaching, and learning missions of their parent colleges and universities. These libraries provide fodder for faculty and student research, as well as valuable workspace for the advancement and transmission of knowledge. As users' information-seeking behaviors and service preferences have evolved over time, academic libraries and their staff have adjusted service and content delivery methods. A recent study by the Online Computer

This article was first presented as a paper at the Library Assessment Conference at Charlottesville, Virginia, USA in 2006.

\begin{abstract}
.
\end{abstract}


PMM

9,3

172
Library Center (OCLC), however, suggests that a dissonance exists between the services and content provided by libraries and those desired and most frequently used by users seeking information (De Rosa et al., 2004). In a follow-up survey conducted to discover how libraries fit into the lives of information seekers, OCLC found "trends toward increased information self-service and seamlessness” (De Rosa, 2005) via increased reliance on online information resources on the part of respondents, and more glaringly, that libraries' share of this unmediated information service environment was well behind that of non-library competitors.

College students reported a similar, although less exaggerated, orientation to their information-seeking behaviors, giving higher favorability ratings to the information available in search engines than to either libraries' physical or online offerings. When asked about their actual usage of electronic information resources, college students reported substantially higher usage of search engines than library web sites; and when asked how they learn about electronic information resources, asking a friend (67 percent) and following links from a found web site (61 percent) easily outpaced asking a librarian (33 percent) or consulting a library web site (36 percent) (De Rosa, 2005). Facing an identifiable gap between the services and content offered and what at least one group of users are choosing to use to find information, academic libraries might ask if their organizational service priorities, and specifically the priorities of library staff, are adequately aligned with those of their users.

Much has been written about the provision of customer service in libraries, about libraries remaining relevant to users, about measuring user perceptions of service quality, and the opinions of librarians regarding the best methods for responding to changes in user behavior[1]. But studies addressing the relative service priorities of library users and library staff are fewer; these (Crawford et al., 1998) are summarized below.

Edwards and Browne (1995) conducted a study investigating if librarians and faculty differ in how they view the quality of information services. A total of 300 faculty members and 55 librarians at four universities in Australia were surveyed regarding indicators of quality; findings showed that while librarians in the sample reported a relatively accurate perception of overall user expectations, they underestimated faculty expectations "about computer-based services, responsiveness in obtaining material, timeliness of service, and the arrangement of materials." Librarians overestimated faculty expectations pertaining to the importance of faculty/librarian relationships and user education programming.

The New Zealand University Libraries Effectiveness Study (NZULES) addressed the question of whether there are different perceptions of effectiveness among the various stakeholders of seven university libraries in New Zealand. Stakeholders were identified as university administrators, senior library staff, other library staff, academic staff, graduate students, and undergraduates. Survey responses were ranked and compared across stakeholder groups. Responses for senior and other library staff had the highest correlation. Responses for senior library staff and other library staff had more moderate correlations with academic staff, graduate students, and undergraduates. Library staff in general placed service and management issues at or near the top of the list, while academic staff rated issues "relating to expert assistance most highly, and [had] a major concern about intellectual access." Graduate students 
focused on library access and access to materials, while undergraduates' concerns centered on the study environment, access to information, and equipment (Cullen and Calvert, 1995).

A study conducted at Glasgow Caledonian University and inspired by NZULES set out to create a set of user-centered performance measures to be used in British academic libraries to improve customer service. Results indicated that each stakeholder group had its own service preferences, but when viewing the ranking of all stakeholders "... it is noticeable that some issues which are traditionally regarded as important by librarians were rated lowly" by other stakeholders. "Staff consistently felt that the capabilities and qualifications of library staff were very important; however, small proportions of stakeholders agreed that the expertise of service desk staff (19 percent), the proportion of staff with professional credentials (13 percent), and the level of staff training and development (24 percent) were "very important" (Crawford et al., 1998).

Taken together, the results of these studies suggest that academic library staff tend to place very high importance on the quality of mediated service interactions, while users may be placing a higher priority on easy access to quality content. Identifying such misalignments can provide useful direction for creating and maintaining service profiles that more closely map to users' stated needs, and thus lead to better support for the research, teaching, and learning missions of parent institutions. Discovering such misalignments in service priorities between library staff and their users can also provide important management information useful for staff development and resource allocation purposes. The current study opens an investigation of potential misalignments between academic library staff and their three primary user groups (faculty, graduate students, and undergraduates), using a sample from the University of Texas at Austin 2005 LibQUAL+ ${ }^{\circledR}$ data.

\section{Methods}

\section{Sample}

This paper is based on the results from the LibQUAL+ ${ }^{\circledR}$ survey completed at the University of Texas at Austin in 2005. The survey covered 15 libraries and four research centers on campus, with 847 useable surveys submitted: 319 from undergraduates, 287 from graduate students, 192 from faculty, and 49 from library staff.

\section{Measures}

LibQUAL+ ${ }^{\circledR}$ is a set of services constructed in response to the Association of Research Libraries' (ARL's) New Measures Initiative. It is an assessment tool for collecting and analyzing customer perceptions of service quality in three areas: affect of service (questions in this category relate to the attitudes and abilities of employees when assisting others); library as place (questions in this category relate to the library facilities and use of space)l and information control (questions in this category focus on collection breadth and scope, the ability of respondents to find information on their own, and the Libraries success in providing information) (Cook et al., 2006).

The survey consists of 22 service statements and a comment box. Respondents are asked to rate each service indicator on three levels (the minimum level of quality that is

\section{Getting our priorities in order}

\author{
173
}


PMM

9,3

acceptable, the desired level of quality, and the current perceived level of service quality) using a Likert scale of 1-9 (see Appendix 1, Figure A1 for sample survey).

\section{Preliminary analysis}

The minimum, perceived, and desired ratings may be used to calculate two kinds of 174 gap scores. The adequacy gap is the difference between a person's minimum level of acceptable service and their perceived rating; the superiority gap is the difference between a person's perceived rating and their desired level of service. A preliminary step in our analysis was to examine the adequacy gap values separately for each of the four user groups using a "gap analysis chart" method developed by the Clemson University Libraries (see Appendix 2, Figure A2 for a sample gap chart). If an adequacy gap is greater than 1.0, the service is perceived at a level above the minimum and is in medium shading on the chart. If the adequacy gap value is negative, the perceived level of service has fallen below the minimum acceptable level; those areas are in dark shading. Services with an adequacy gap below one, and with values that have declined over two or more years, are in light shading, indicating areas of potential danger. In addition to examining the adequacy gaps, we also ranked each item according to its "desired mean," or average level of desired quality, within each user group. For example, in 2005 faculty reported a desired mean score of 8.67 for "Print and/or electronic journal collections I require for my work," a desired mean of 8.62 for "Making electronic resources accessible from my home or office," and 8.37 for "A library web site enabling me to locate information on my own." These three items had the highest desired means for faculty in 2005; accordingly, their respective desired mean rankings are 1, 2 and 3 (Cook et al., 2005).

The difference in the desired mean rankings between the user groups in 2005 caught our attention. For faculty and graduate students, eight out of the top ten ranked items were in the information control area. For undergraduates, half fell into information control, while the others were scattered through other areas. For library staff, however, the majority of the top ten items fell into affect of service. This apparent divergence between how library staff and user groups rank the relative importance of the survey items, and thus the services represented by those items, led us to question whether these apparent differences in priorities were statistically significant.

In order to perform statistical analysis on the data, it was necessary to define the service priorities of each individual respondent. To do so, we re-scaled each respondent's desired score for each item to reflect the degree to which the item was above or below the average desired level across all items for that respondent.

As an illustration, suppose that Betty, a member of the library staff, has very high expectations for every item on the survey; her average desired score across all 22 items is 8.8. However, Betty rates some items as more important than others. For example, her desired score for the library as place item "comfortable and inviting location" is only a 7, while her desired score for the affect of service item "employees who deal with users in a caring fashion" is a 9. Betty places a higher priority on caring for users than in creating an inviting atmosphere. When Betty's scores are re-scaled around her individual mean of 8.8 , her new scores are -1.8 for inviting location, indicating that it is a below-average personal priority, and +0.2 for caring for users, indicating that it is an above-average personal priority. 
By re-scaling scores around each respondent's personal average, we created a personal priority index (hereafter termed the "priority score") that eliminated individual differences in absolute standards and allowed comparisons of relative standards across items. These priority scores were subjected to the final statistical analysis, as discussed below.

\section{Results}

Across the sample, average priority scores for each item ranged from a low of -1.94 (for the library as place item "community space for group learning and group study") to a high of +0.74 (for the information control item "a library web site enabling me to locate information on my own"). Table I shows the average scores for each item. In general, we refer to items with scores between \pm 0.10 as being an "average" priority, scores between \pm 0.50 as being a "moderately" high or low priority, and scores above \pm 0.50 as being a "very" high or low priority. Accordingly, group learning space is, on average across all groups, a very low priority, while a library web site is a very high priority.

\author{
Getting our \\ priorities in order \\ pric
}

\title{
Information control
}

The printed library materials I need for my work

The electronic information resources I need

Modern equipment that lets me easily access the

information I need

Easy-to-use access tools that allow me to find things on my

own

Making information easily accessible for independent use

Print and/or electronic journals I require for my work

Making electronic resources accessible from my home or office

A library web site enabling me to locate information on my own

Mean Standard deviation

\section{Affect of service}

Employees who instill confidence in users

Giving users individual attention

Employees who are consistently courteous

Readiness to respond to users' questions

Employees who have the knowledge to answer user questions

Employees who deal with users in a caring fashion

Employees who understand the needs of their users

Willingness to help users

Dependability in handling users' service problems

$\begin{array}{ll} & \\ -0.01 & 2.41 \\ +0.68 & 1.74 \\ +0.55 & 1.66 \\ +0.54 & 1.70 \\ +0.50 & 1.69 \\ +0.26 & 2.53 \\ +0.80 & 1.84 \\ & \\ +0.77 & 1.60 \\ & \\ -0.57 & 2.18 \\ -0.81 & 2.16 \\ +0.39 & 1.62 \\ +0.05 & 1.90 \\ & \\ +0.24 & 1.83 \\ -0.16 & 1.94 \\ -0.20 & 2.10 \\ +0.01 & 1.84 \\ -0.48 & 2.70 \\ & \\ -0.19 & 2.09 \\ -0.30 & 2.30 \\ +0.05 & 1.88 \\ -0.23 & 2.28 \\ -1.87 & 3.22\end{array}$

Library as a place

Library space that inspires study and learning

Quiet space for individual activities

A comfortable and inviting location

A getaway for study, learning, or research

Community space for group learning and group study

$-1.87$

2.28

2.41

1.66

1.70

1.69

1.84

1.60

2.18

1.62

1.90

1.83

2.10

1.84

2.70

2.09

2.30

3.22 
PMM

9,3

176
The priority scores for the 22 items were compared between the user groups using a repeated-measures analysis of variance (MANOVA), with item as a within-subjects factor with 22 levels, and group as a between-subjects factor with four levels. Mauchly's test indicated that the sphericity assumption underlying repeated-measures ANOVA was violated for this sample. Accordingly, we report the Wilks' Lamba multivariate $F$-test, which does not require the sphericity assumption. Overall, there was a significant main effect of item, $F(21,823)=19.37, p<0.001$, indicating that the 22 items differed in their average priorities, as well as a significant group by item interaction, $F(63,2,457)=6.23, p<0.001$, indicating that the four user groups tended to differentially prioritize at least some items. As described above, priority scores were created by centering each item for a particular individual on that individual's mean; accordingly, the mean for each individual across the 22 new priority scores was zero. Consequently, multivariate means for each group were also zero, rendering the multivariate main effect of group irrelevant.

To determine which items contributed to the group by item interaction, we performed follow-up univariate tests of the effect of group for each item. Significant univariate tests were followed by post hoc pairwise comparisons to compare the library staff to each of the other three groups.

\section{Information control}

Univariate tests for information control were significant for seven of the eight items. The single non-significant item was "modern equipment that lets me easily access the information I need." Differences between library staff and the other groups for the seven items are shown in Figure 1. Overall, library staff tended to set a lower priority on Information Control items than did graduate students and faculty, while prioritizing the items similarly to undergraduates.

For "easy-to-use access tools that allow me to find things on my own," $F$ (3, $843)=4.64, p<0.01$, staff (mean $=0.17)$ prioritized the item lower than faculty (mean $=0.81, p<0.05$ ), marginally lower than graduate students (mean $=0.66$, $p=0.06$ ), and similarly to undergraduates. For "making information easily accessible for independent use, $F(3,843)=3.04, p<0.05$, staff (mean $=0.03$ ) prioritized the item significantly lower than both faculty (mean $=0.72, p<0.01$ ) and graduate students (mean $=0.55, p<0.05$ ), but similarly to undergraduates. For "making electronic resources accessible from my home or office," $F(3,843)=17.27, p<0.001$, staff (mean $=-0.52$ ) rated the item significantly lower than all three groups, faculty (mean $=1.33, \quad p<0.001)$, graduate students (mean $=0.96, \quad p<0.001$ ), and undergraduates (mean $=0.55, p<0.001$ ). For "a library web site enabling me to locate information on my own," $F(3,843)=11.52, p<0.001$, staff (mean $=0.44$ ) prioritized the item lower than faculty (mean $=1.18, p<0.01$ ) and graduate students (mean $=0.94, p<0.05$ ), but similarly to undergraduates. For "modern equipment that lets me easily access the information I need," there were no differences, $F$ (3, $843)=1.53$, ns. For "print and/or electronic journal collections I require for my work," $F(3,843)=26.42, p<0.001$, staff (mean $=-0.42)$ prioritized the item lower than both faculty $($ mean $=1.02, p<0.001$ ) and graduate students (mean $=0.82$, $p<0.001$ ), but similarly to undergraduates. For "the printed library materials I need for my work," $F(3,843)=11.46, p<0.001$, staff $($ mean $=0.17)$ prioritized the 

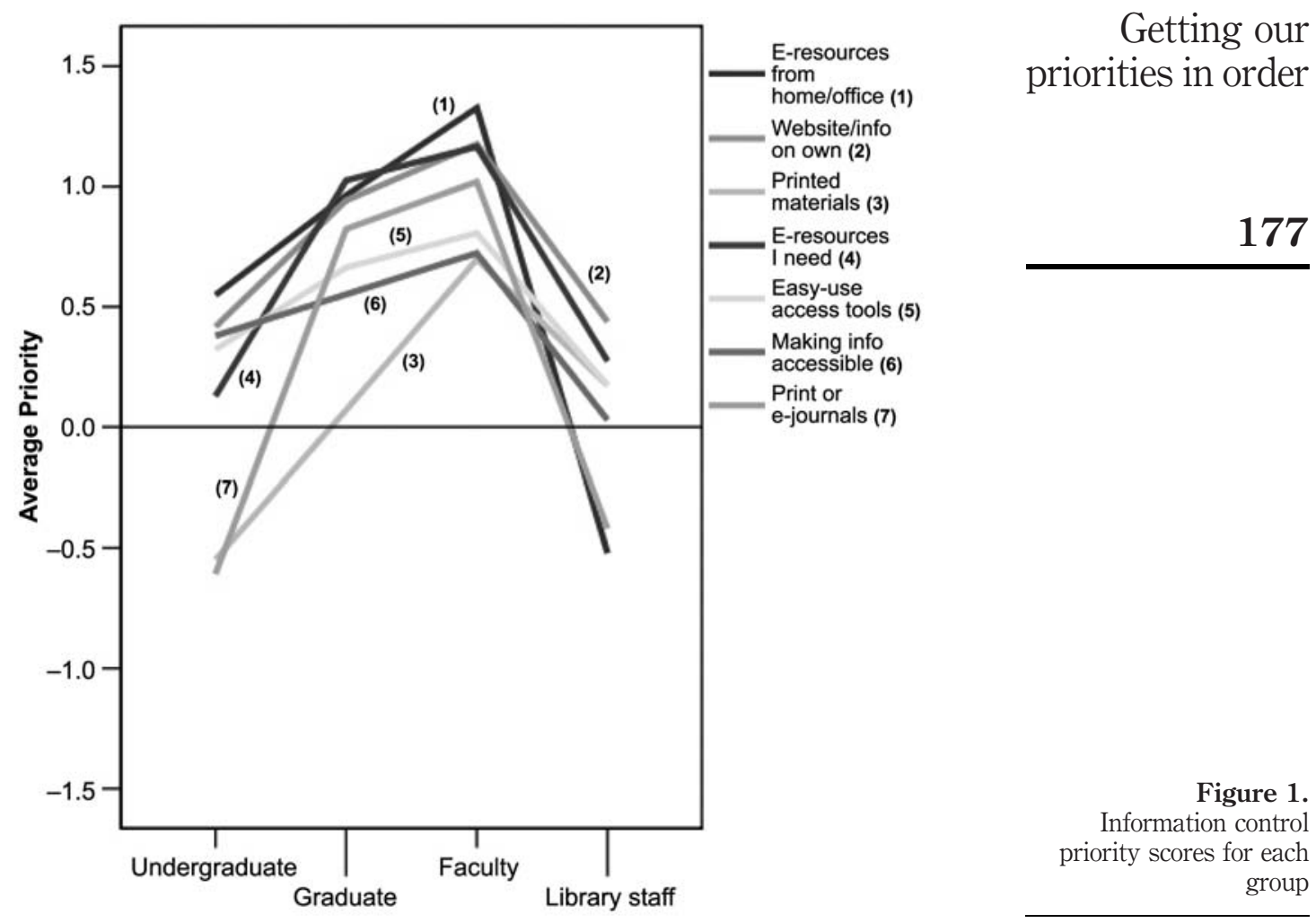

Figure 1. Information control priority scores for each group

item similarly to faculty and graduate students, but higher than undergraduate students (mean $=-0.55, p<0.05$ ). For "the electronic information resources I need," $F(3,843)=21.86, p<0.001$, staff $($ mean $=0.28)$ prioritized the item similarly to undergraduates, but lower than both faculty (mean $=1.17, p<0.001$ ) and graduate students (mean $=1.03, p<0.01$ ).

\section{Affect of service}

Across the nine affect of service items, five had significant univariate tests, and one was marginally significant. Where there were significant differences, library staff tended to prioritize these items more highly than the other groups. Non-significant items were "Employees who deal with users in a caring fashion," $F(3,843)=1.62$, ns, "willingness to help users," $F(3,843)=1.14$, ns, and dependability in handling users' service problems," $F(3,843)=1.66$, ns. For "readiness to respond to users' questions," $F(3,843)=2.48, p=0.06$, the univariate test was only marginally significant, and there were no significant differences between library staff and the other three groups. Two other items had significant univariate tests, indicating differences in priorities between at least two of the four groups, but those differences were not between the library staff and the other three groups: "employees who understand the needs of their 
PMM

9,3

178 users," $F(3,843)=3.90, p<0.01$, and "employees who have the knowledge to answer user questions," $F(3,843)=2.72, p<0.05$.

Only three items had both significant univariate tests and significant pairwise comparisons between library staff and the other groups. Results for these items are shown in Figure 2. For "employees who instill confidence in users," $F(3,843)=5.78$, $p<0.001$, staff (mean $=0.36$ ) prioritized the item marginally higher than faculty (mean $=-0.27, p=0.07$ ) and significantly higher than both graduate students (mean $=-0.65, p<0.01$ ) and undergraduates (mean $=-0.82, p<0.001$ ). For "giving users individual attention," $F(3,843)=9.72, p<0.001$, staff (mean $=-0.30$ ) prioritized the item similarly to faculty, but more highly than graduate students (mean $=-1.22, \quad p<0.01$ ) and marginally higher than undergraduates (mean $=-0.90, p=0.07$ ). For "employees who are consistently courteous," $F(3$, $843)=6.21, p<0.001$, staff (mean $=0.64$ ) prioritized the item similarly to faculty and graduate students, but marginally higher than undergraduates (mean $=0.20$, $p=0.07)$.

\section{Library as place}

All five library as place items showed significant univariate tests of differences between groups, as shown in Figure 3. Overall, library staff tended to prioritize

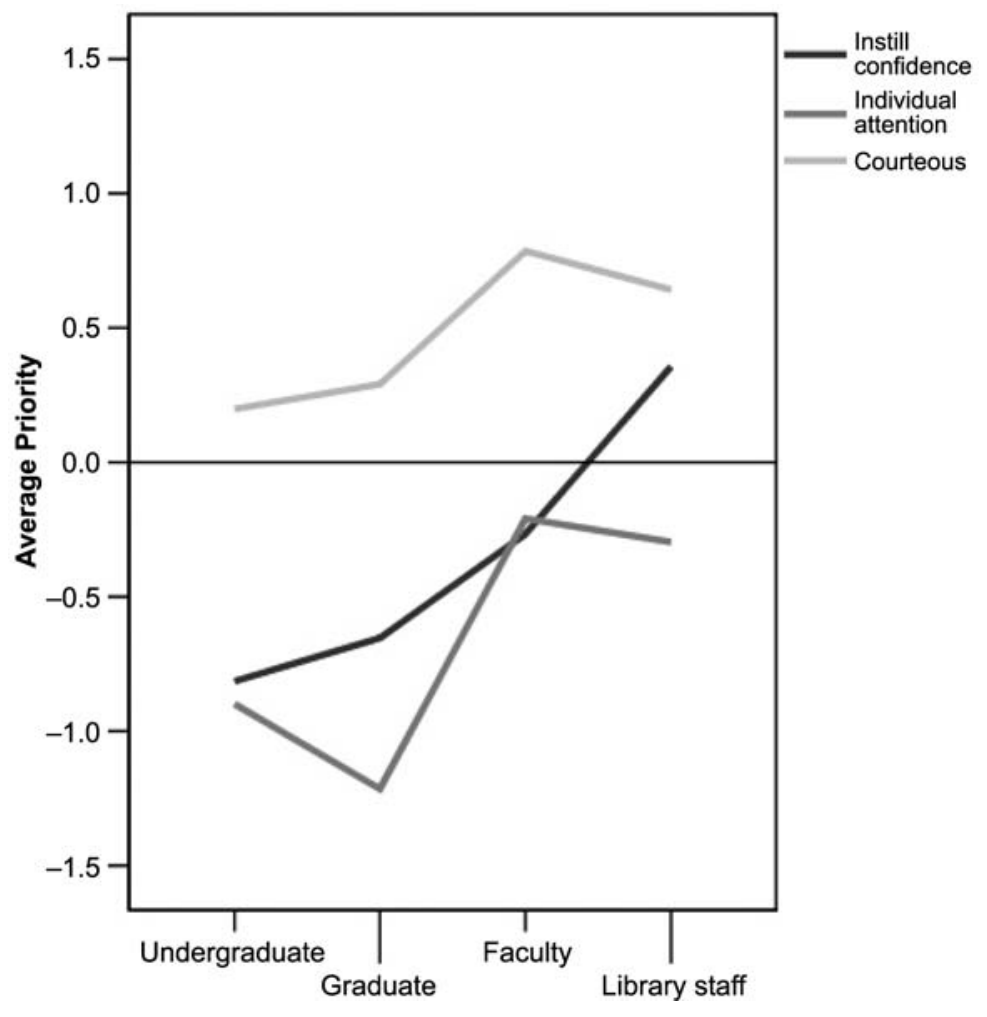

Figure 2.

Affect of service priority scores for each group 


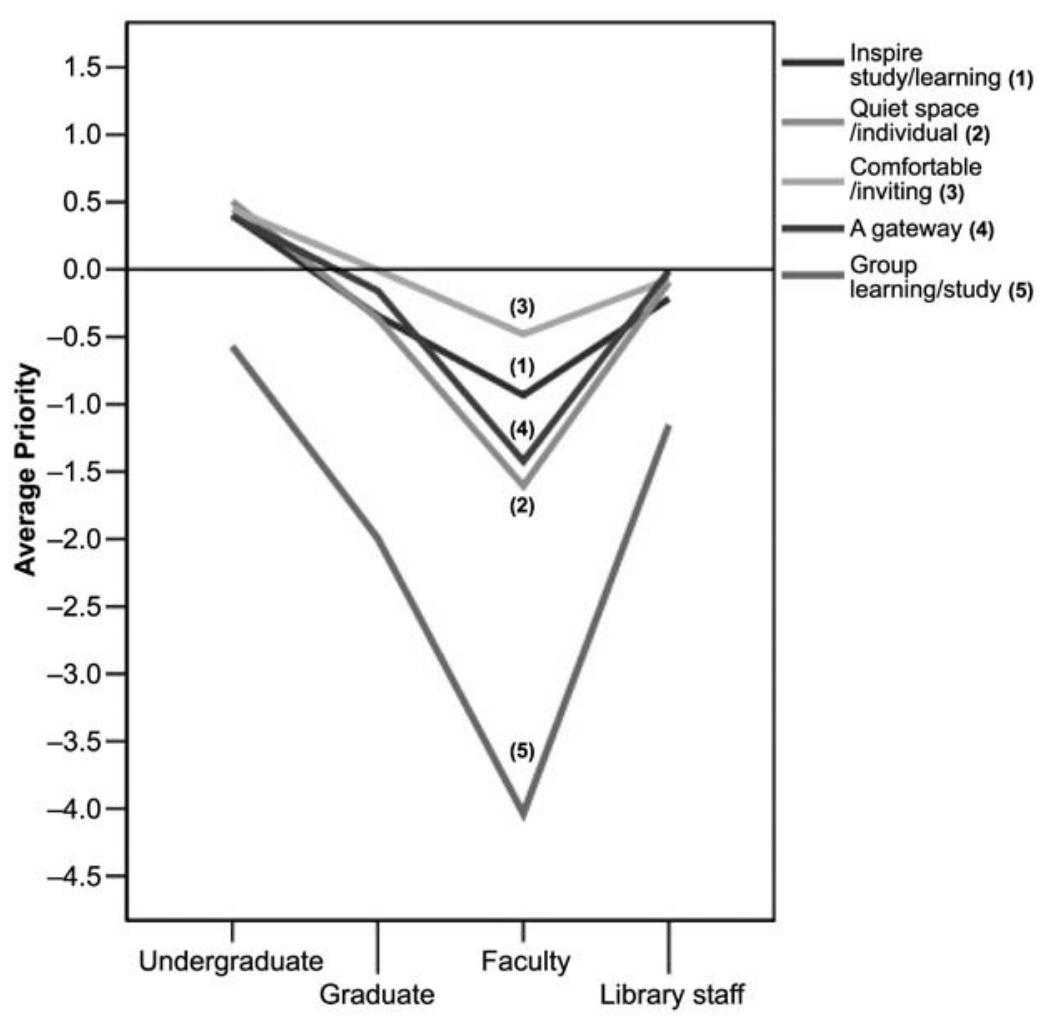

Getting our priorities in order

179

Figure 3.

Library as a place priorities for each group

these items more highly than faculty, similarly to graduate students, and lower than undergraduate students. For "a getaway for study, learning, or research," $F$ $(3,843)=28.14, p<0.001$, staff (mean $=-0.01)$ prioritized the item higher than faculty (mean $=-1.42, \quad p<0.001$ ), but similarly to graduate students and undergraduates. For "library space that inspires study and learning," $F$ (3, $843)=18.18, p<0.001$, staff $($ mean $=-0.22$ ) prioritized the item higher than faculty (mean $=-0.93, p<0.05$ ), similarly to graduate students, and lower than undergraduates (mean $=0.51, p<0.05$ ). For "quiet space for individual activities," $F(3,843)=38.19, p<0.001$, staff $($ mean $=-0.09)$ rated the item higher than faculty (mean $=-1.61, p<0.001$ ), similarly to graduate students, and marginally lower than undergraduates (mean $=0.51, p=0.07$ ). For "a comfortable and inviting location," $F(3,843)=10.31, p<0.001$, staff (mean $=-0.07)$ prioritized the item similarly to faculty and graduate students, but marginally lower than undergraduates (mean $=0.45, p=0.07$ ). Finally, for "community space for group learning and group study," $F(3,843)=56.55, p<0.001$, staff (mean $=-1.15$ ) rated the item similarly to undergraduates, but higher than faculty (mean $=-4.04$, $p<0.001$ ) and marginally higher than graduate students (mean $=-2.00$, $p=0.07)$. 
PMM

9,3

180

\section{Discussion}

The most substantive result of this analysis is that library staff set a lower priority on several information control items than do users. Specifically, staff prioritized the items "easy-to-use access tools that allow me to find things on my own," "a library web site enabling me to locate information on my own," "making information easily accessible for independent use," and "the electronic information resources I need" lower than faculty and graduate students, and the item "making electronic resources accessible from my home or office" lower than all three user groups. This misalignment of service priorities is potentially problematic when viewed in conjunction with how these users report they use library and non-library resources when seeking information.

In 2005, 81 percent of the University of Texas at Austin faculty, graduate students, and undergraduates reported using Google, Yahoo!, or other non-library information gateways daily, versus only 16 percent for resources found in the physical library, and 32 percent for resources found via a library web site (Cook et al., 2005). Users more often choose search engines over libraries or library web sites to begin information searches, and they rate search engines higher than librarians on the quality and quantity of information found (De Rosa, 2005). In general, users clearly prioritize the ability to engage in self-directed information seeking on their own terms, utilizing easy-to-use online information resources. The misalignment between library staff and users in terms of the prioritization of information control is a cause for concern. If library staff do not set a high priority upon meeting users' evolving needs and desires in this area, academic libraries will find it increasingly difficult to remain relevant to users who will continue to pursue non-library alternatives.

Although library staff priorities tended to align more consistently with the other groups on affect of service items, staff prioritized the item "employees who instill confidence in users" higher than all three groups, and "giving users individual attention" and "employees who are consistently courteous" similarly to faculty, but higher than graduate students and undergraduates. That library staff place a high priority on courteous, high quality service interactions is not surprising, and if anything should be seen as positive confirmation of their commitment to serving users well. But when viewed with the aforementioned misalignments on several information control items, these differences in affect of service priorities provide some confirmation that users are more concerned with unmediated access to quality, easy-to-use content and less on in-person, one-on-one interactions with library staff. Echoing Edwards and Browne, we see that users are more focused on getting the information they need and less worried about the attributes of the staff providing library services.

On library as place items, library staff tended to prioritize higher than faculty, similarly to graduate students, and lower than undergraduates. Staff prioritized all but one item, "a comfortable and inviting location," higher than faculty. On four of five items, library staff prioritized similarly to graduates students, with the exception of "a community space for group learning and group study," which staff prioritized marginally higher. Staff prioritized the items "library space that inspires study and learning" lower than undergraduates and "quiet space for individual activities" and "a comfortable and inviting location" marginally lower. These results clearly reflect the disparate ways in which our core user groups tend to utilize our physical facilities. Faculty members often view our facilities as warehouses for content - the fodder for 
furthering their research and teaching. Undergraduates often view our physical spaces as workspace, and prioritize comfortable space that inspires learning. Graduate students tend to straddle both views - they value the content necessary for successful research, but also use the library as workspace. Although library staff priorities are marginally misaligned on multiple library as place items, these results should serve as a reminder for both staff and library managers of just how differently our core user groups prioritize service when it comes to library facilities.

Referring to the 1993 NZULES study, Cullen (1996) states that "[1]ibrary staff again demonstrate their desire to be responsive to user needs ... But their aspirations and their perceptions of what users want are not close to reality." While our results do not indicate anything close to a break with reality between library staff and our core user groups, we do see indications of misalignment between the service priorities of staff and those of users in various contexts, especially in the area of information control. When viewed with the less pronounced but evident misalignment on some affect of service items, this incongruity might cause concern in light of how users report they actually use library and non-library resources when seeking information. It seems library staff have not yet internalized the extent to which many users prioritize unmediated access to easy-to-use, quality content and services and de-emphasize traditional mediated interactions with library staff. This poses a challenge for library leadership to work with staff to better align organizational service priorities with evolving user needs and demonstrated behaviors. The job of aligning staff and user service priorities is complicated by the disparate, and sometimes conflicting, service priorities of our core user groups, especially faculty and undergraduates in terms of how they use both our physical facilities and deep research collections.

\section{Limitations}

This analysis rests on the assumptions that users' desired scores on the LibQUAL $+{ }^{\circledR}$ survey can be used to indicate the relative importance of a survey item (and the service that item represents), as well as the basis of a ranking of users' service priorities. The survey instrument does not ask respondents to prioritize the items in order of importance, thus our creation of a priority index based on desired mean rankings.

Other possible limitations include the sample size of library staff included in the analysis and the point of view staff take when responding to the survey. In 2005, the University of Texas Libraries employed 138 professional staff and 298 support staff. A total of 49 library staff submitted usable surveys (8.9 percent of total library staff; 5.7 percent of total usable surveys submitted). Given the low response rate for library staff, it is possible that results were affected by some type of response bias. For example, it may be that only staff most committed to high-quality service were motivated to respond to the survey. However, such a bias would more likely impact absolute desired ratings and would less likely impact the relative priorities used in this analysis. When library staff are sent an e-mail request to respond to the survey, they are asked "to complete the survey and let us know how you think we are meeting our users' expectations in these areas." It is unclear whether staff choose to respond from a user's point of view or from that of a service provider. It is also unclear if this difference in point of view would significantly affect desired ratings given a library staff member's dual roles as both information provider and consumer. Is it possible for library staff to 
PMM

9,3

182 successfully distinguish between these roles? There is much evidence that we all suffer from the inability to eliminate this type of bias from our interpretation of information (Cram, 1999 quoting Messick and Sentis, 1979; Messick, 1995; Bazerman et al., 1997).

\section{Future research}

An obvious direction for extending this analysis is to investigate whether these results can be generalized across the entire Association of Research Libraries (ARL) cohort. Are the misalignments in service priorities evident in the University of Texas Libraries data reflected in the ARL cohort data for the same survey administration? If so, library leaders might do well to re-evaluate their understanding of the service priorities of library staff in academic libraries across North America, their relationship to the priorities of their core users, and to academic libraries' ability to support the teaching, learning, and research missions of their parent institutions.

It might also be useful to extend the analysis historically to investigate any possible divergence of service priorities between staff and users over time. Are the service priorities of staff and users diverging over time? If so, is this divergence accelerating as user desires and behaviors rapidly evolve? What implications would results of this nature have on future staff development considerations on the part of library leaders? Several years of survey data at both the local and cohort levels are available for attempting such an analysis.

Finally, any analysis of the alignment of staff and user service priorities, especially one that purports to indicate some misalignment between the two, begs the question of whether there are circumstances when staff service priorities need not necessarily align with those of users. Should users' service priorities necessarily drive organizational service priorities, and thus those of staff, for academic libraries? Many library leaders have answered this question affirmatively, and the creation and large-scale implementation of user-centered quality assessment tools like LibQUAL+ ${ }^{\circledR}$ show widely held support for utilizing users' service preferences in administrative decision making and resource planning. A productive next step would be for library leaders to use the information gained by identifying misalignments in priorities between staff and users to adjust service profiles to better meet users' needs and preferences. Library leaders should provide clear direction and support for staff development efforts to help bridge any identifiable gaps between the services prioritized by users and library staff. Appropriately aligning staff service priorities with those of users is a necessary step for academic libraries to better engage the research, teaching, and learning missions of their parent institutions.

\section{Note}

1. Items on customer satisfaction are: Altman and Hernon (1998); Bessler (1994); Hernon and Whitman (2001); Leonicio (2001); Quinn (1997); Soete (1998); and Weingand (1997). Items remaining relevant to users are: Anwar (2005); Ferguson and Bunge (1997); Lougee (2002); Rice-Lively and Racine (1997); Rieh (1999); and Simmons-Welburn (2000). Items on user perceptions of service quality are: Baker and Wilfrid (1991); Calvert and Hernon (1997); Carnovsky (1959); Cook and Heath (2001); Cook (2002); Du Mont and Du Mont (1979); Hernon and Altman (1998); Nitecki and Hernon (2000); Nitecki (1997); Parasuraman et al. (1985); Zeithaml et al. (1990); and Van House and Childers (1990). Items on responding to changes in user behavior are: Ferguson (2000); Hirshon (1996); Maness (2006); Stern (2002); Troll (2001). 
General items are: Buckland (1992); Calvert and Cullen (2003); Cook (2001); Crawford (2003); Cullen (2001, 1996); Harer and Cole (2005); Hernon and Nitecki (2001); Hernon et al. (1999); Kyrillidou (2005); ARL (n.d.); and McDonald and Micikas (1994).

\section{References}

Altman, E. and Hernon, P. (1998), "Service quality and customer satisfaction do matter", American Libraries, Vol. 29 No. 7, pp. 53-4.

Anwar, M. (2005), "Changing nature of information and user needs in the modern electronic networked environment, challenge for libraries", Pakistan Library and Information Science Journal, Vol. 36 No. 2, pp. 9-13.

Association of Research Libraries (ARL) (n.d.), LibQUAL+ ${ }^{\mathrm{TM}}$ : Charting Library Service Quality, ARL, Washington, DC, available at: www.libqual.org/ (accessed September 13, 2006).

Baker, S.L. and Wilfrid, L.F. (1991), The Measurement and Evaluation of Library Services, 2nd ed., Information Resources Press, Arlington, VA.

Bazerman, M.H., Morgan, K.P. and Loewenstein, G.F. (1997), "The impossibility of auditor independence", Sloan Management Review, Summer, pp. 89-94.

Bessler, J.M. (1994), Putting "Service” into Library Staff Training: A Patron-centered Guide, American Library Association, Chicago, IL.

Buckland, M.K. (1992), Redesigning Library Services: A Manifesto, American Library Association, Chicago, IL, available at: http://sunsite.berkeley.edu/Literature/Library/Redesigning/

Calvert, P.J. and Cullen, R. (2003), "Factors affecting the delivery of service quality", paper presented at LIANZA Conference 2003: "Oceans of Opportunity: Whakawhitihia te Moana”, Napier.

Calvert, P.J. and Hernon, P. (1997), "Surveying service quality within university libraries", Journal of Academic Librarianship, Vol. 23 No. 5, pp. 408-15.

Carnovsky, L. (1959), "Evaluation of library services", UNESCO Bulletin for Libraries, Vol. 13 No. 10 , pp. 221-5.

Cook, C.C. (2001), "A mixed-methods approach to the identification and measurement of academic library service quality constructs: LibQUAL $+{ }^{\mathrm{TM}}$ ”, $\mathrm{PhD}$ dissertation, Texas A\&M University, College Station, TX.

Cook, C.C. (Ed.) (2002), "The maturation of assessment in academic libraries: the role of LibQUAL $+{ }^{\mathrm{TM}}$, Performance Measurement and Metrics, Vol. 3 No. 2, pp. 34-112.

Cook, C.C. and Heath, F. (2001), "Users' perceptions of library service quality: a LibQUAL+2001 qualitative study", Library Trends, Vol. 49 No. 4, pp. 548-84.

Cook, C.C., Heath, F.M., Thompson, B., Hoseth, A., Kyrillidou, M., Sousa, J.D. and Webster, D. (2005), LibQUAL+ ${ }^{\circledR} 2005$ Survey: University of Texas at Austin, Association of Research Libraries, Washington, DC, p. 64.

Cook, C.C., Heath, F.M., Thompson, B., Hoseth, A., Kyrillidou, M., Sousa, J.D. and Webster, D. (2006), LibQUAL+® 2006 Survey: University of Texas at Austin, Association of Research Libraries, Washington, DC.

Cram, J. (1999), "Six impossible things before breakfast: a multidimensional approach to measuring the value of libraries", Keynote address at 3rd Northumbria International Conference on Performance Measurement in Libraries and Information Services, Newcastle, September.

Crawford, J.D. (2003), "Reviewing a programme of evaluation in an academic library: the case of Glasgow Caledonian University”, Performance Measurement and Metrics, Vol. 4 No. 3, pp. 113-21. 
PMM

9,3

184

Crawford, J.D., McLelland, D. and Pickering, H. (1998), "The stakeholder approach to the construction of performance measures", Journal of Librarianship and Information Science, Vol. 30 No. 2, pp. 87-112.

Cullen, R.J. (1996), "New Zealand university libraries effectiveness project: dimensions and concepts of organizational effectiveness", Library and Information Science Research, Vol. 18 No. 2, pp. 99-119.

Cullen, R.J. (2001), "Perspectives on user satisfaction surveys", Library Trends, Vol. 49 No. 4, pp. 662-86.

Cullen, R.J. and Calvert, P.J. (1995), "Stakeholder perceptions of university library effectiveness", Journal of Academic Librarianship, Vol. 21 No. 6, pp. 438-48.

De Rosa, C.L. (2005), Perceptions of Libraries and Information Resources, OCLC, Dublin, OH.

De Rosa, C., Dempsey, L. and Wilson, A. (2004), The 2003 OCLC Environmental Scan: Pattern Recognition, OCLC, Dublin, OH.

Du Mont, R.R. and Du Mont, P.F. (1979), "Measuring library effectiveness: a review and an assessment”, Advances in Librarianship, Vol. 9, pp. 103-41.

Edwards, S. and Browne, M. (1995), "Quality in information services: do users and librarians differ in their expectations?", Library and Information Science Research, Vol. 17 No. 2, pp. 163-82.

Ferguson, C.D. (2000), “'Shaking the conceptual foundations,' too: integrating research and technology support for the next generation of information service", College and Research Libraries, Vol. 61 No. 4, pp. 300-11.

Ferguson, C.D. and Bunge, C.A. (1997), "The shape of services to come: values-based reference service for the largely digital library", College and Research Libraries, Vol. 58 No. 3, pp. 252-65.

Harer, J.B. and Cole, B.R. (2005), "The importance of the stakeholder in performance measurement: critical processes and performance measures for assessing and improving academic library services and programs”, College and Research Libraries, Vol. 66 No. 2, pp. 149-70.

Hernon, P. and Altman, E. (1998), Assessing Service Quality: Satisfying the Expectations of Library Customers, American Library Association, Chicago, IL.

Hernon, P. and Nitecki, D.A. (2001), "Service quality: a concept not full explored", Library Trends, Vol. 49 No. 4, pp. 687-708.

Hernon, P. and Whitman, J.R. (2001), Delivering Satisfaction and Service Quality: A Customer-based Approach for Libraries, American Library Association, Chicago, IL.

Hernon, P., Nitecki, D.A. and Altman, E. (1999), "Service quality and customer satisfaction: an assessment and future directions", The Journal of Academic Librarianship, Vol. 25 No. 1, pp. 9-17.

Hirshon, A. (1996), "Running with the red queen: breaking new habits to survive in the virtual world", Advances in Librarianship, Vol. 20, pp. 1-26.

Kyrillidou, M. (2005), ARL New Measures Initiative, Association of Research Libraries, Washington, DC, available at: www.arl.org/stats/newmeas/index.html (accessed September 13, 2006).

Leonicio, M. (2001), "Going the extra mile: customer service with a smile", The Reference Librarian, Vol. 34 No. 72, pp. 51-6.

Lougee, W.P. (2002), Diffuse Libraries: Emergent Roles for the Research Library in the Digital Age, Perspectives on the Evolving Library, ERIC, ED 471954, Council on Library and Information Resources, Washington, DC. 
McDonald, J.A. and Micikas, L.B. (1994), Academic Libraries: The Dimensions of Their Effectiveness, Greenwood Press, Westport, CT.

Maness, J. (2006), “Library 2.0 theory: Web 2.0 and its implications for libraries”, Webology, Vol. 3 No. 2, Article 25, available at: www.webology.ir/2006/v3n2/a25.html (accessed September 13, 2006).

Messick, D.M. (1995), "Equality, fairness, and social conflict”, Social Justice Research, Vol. 8 No. 2, pp. 153-73.

185

Messick, D.M. and Sentis, K.P. (1979), "Fairness and preference”, Journal of Experimental Social Psychology, Vol. 15 No. 4, pp. 418-34.

Nitecki, D.A. (1997), "Assessment of service quality in academic libraries: focus on the applicability of SERVQUAL", Proceedings of the 2nd Northumbria International Conference on Performance Measurement in Libraries and Information Services, Information North for the Department of Information and Library Management, Newcastle upon Tyne, pp. 181-96.

Nitecki, D.A. and Hernon, P. (2000), "Measuring service quality at Yale University's libraries", The Journal of Academic Leadership, Vol. 26 No. 4, pp. 259-73.

Parasuraman, A., Zeithaml, V.A. and Berry, L.L. (1985), “A conceptual model of service quality and its implications for future research", Journal of Marketing, Vol. 49 No. 4, pp. 41-50.

Quinn, B. (1997), "Adapting service quality concepts to academic libraries", The Journal of Academic Librarianship, Vol. 23 No. 5, pp. 359-69.

Rice-Lively, M.L. and Racine, J.D. (1997), "The role of academic librarians in the era of information technology", Journal of Academic Librarianship, Vol. 23 No. 1, pp. 31-42.

Rieh, S.Y. (1999), "Changing reference service environment: a review of the perspectives of managers, librarians, and users", Journal of Academic Librarianship, Vol. 25 No. 3, pp. 178-86.

Simmons-Welburn, J. (2000), Changing Roles of Library Professionals, SPEC Kit 256, Association of Research Libraries, Office of Leadership and Management Services, Washington, DC.

Soete, G.J. (1998), Customer Service Programs in ARL libraries, SPEC Kit 231, Office of Leadership and Management Services, Washington, DC.

Stern, D. (2002), "User expectations and the complex reality of online research efforts", Science and Technology Libraries, Vol. 22 Nos 3/4, pp. 137-48.

Troll, D.A. (2001), How and Why Are Libraries Changing?, Digital Library Federation, Washington, DC, available at: www.diglib.org/use/whitepaper.htm (accessed September 13, 2006).

Van House, N.A. and Childers, T. (1990), "Dimensions of public library effectiveness II: library performance", Library and Information Science Research, Vol. 12 No. 2, pp. 131-53.

Weingand, D.E. (1997), Customer Service Excellence: A Concise Guide for Librarians, American Library Association, Chicago, IL.

Zeithaml, V.A., Parasuraman, A. and Berry, L.L. (1990), Delivering Quality Service: Balancing Customer Perceptions and Expectations, Free Press, New York, NY.

(The Appendices can be found on the next page)

\section{Corresponding authors}

Jocelyn S. Duffy can be contacted at: jduffy@pdx.edu and Damon E. Jaggers can be contacted at: djaggars@columbia.edu 
PMM

9,3

\section{6

\section{University of Texas Libraries | THE UNIVERSITY OF TEXAS AT AUSTIN}

\section{University of Texas at Austin Welcome!}

We are committed to improving your library services. Better understanding your expectations will help us tailor those services to your needs.

We are conducting this survey to measure library service quality and identify best practices through the Association of Research Libraries' LibQUAL+ ${ }^{\mathrm{TM}}$ program.

Please answer all items. The survey will take about 10 minutes to complete. Thank you for your participation!

Please rate the following statements ( 1 is lowest, 9 is highest) by indicating:

Minimum - the number that represents the minimum level of service that you would find acceptable

Desired - the number that represents the level of service that you personally want

Perceived -- the number that represents the level of service that you believe our library currently provides

For each item, you must EITHER rate the item in all three columns OR identify the item as "N/A" (not applicable). Selecting "N/A" will override all other answers for that item.

\begin{tabular}{|c|c|c|c|c|c|}
\hline \multirow{2}{*}{\multicolumn{2}{|c|}{ When it comes to... }} & $\begin{array}{c}\text { My Minimum } \\
\text { Service Level Is }\end{array}$ & $\begin{array}{c}\text { My Desired } \\
\text { Service Level Is }\end{array}$ & $\begin{array}{c}\text { Perceived } \\
\text { Service } \\
\text { Performance Is }\end{array}$ & \multirow[t]{2}{*}{ N/A } \\
\hline & & High & Low & Low & \\
\hline 1) & $\begin{array}{l}\text { Employees who instill confidence in } \\
\text { users }\end{array}$ & 123456789 & 1233456789 & 123456789 & N/A \\
\hline 2) & $\begin{array}{l}\text { Making electronic resources } \\
\text { accessible from my home or office }\end{array}$ & 1233456789 & 12234556789 & 123456789 & N/A \\
\hline 3) & $\begin{array}{l}\text { Library space that inspires study and } \\
\text { learning }\end{array}$ & 1233456789 & 12234456789 & 123456789 & N/A \\
\hline 4) & Giving users individual attention & 123456789 & 123456789 & 123456789 & N/A \\
\hline 5) & $\begin{array}{l}\text { A library Web site enabling me to } \\
\text { locate information on my own }\end{array}$ & 123456789 & 1233456789 & 123456789 & N/A \\
\hline 6) & $\begin{array}{l}\text { Access to photocopying and printing } \\
\text { facilities }\end{array}$ & 123456789 & 12334566789 & 123456789 & N/A \\
\hline
\end{tabular}

(continued)
Figure A1.

Sample LibQUAL+ ${ }^{\circledR}$ survey

\section{$($ continued)}


Getting our

\begin{tabular}{|c|c|c|c|c|c|}
\hline 7) & $\begin{array}{l}\text { Employees who are consistently } \\
\text { courteous }\end{array}$ & 123456789 & 12234556789 & 12234556789 & N/A \\
\hline 8) & $\begin{array}{l}\text { The printed library materials I need for } \\
\text { my work }\end{array}$ & 12334566789 & 12234456788 & 12234566789 & N/A \\
\hline 9) & Quiet space for individual activities & 1233456789 & 1233456789 & 1234566789 & N/A \\
\hline 10) & $\begin{array}{l}\text { Readiness to respond to users' } \\
\text { questions }\end{array}$ & 1233456789 & 122344567889 & 123456789 & N/A \\
\hline 11) & $\begin{array}{l}\text { The electronic information resources I } \\
\text { need }\end{array}$ & 123456789 & 122345567889 & 1233456789 & N/A \\
\hline 12) & $\begin{array}{l}\text { Making me aware of library resources } \\
\text { and services }\end{array}$ & 1234566789 & 12334566789 & 1233456789 & N/A \\
\hline 13) & $\begin{array}{l}\text { Employees who have the knowledge } \\
\text { to answer user questions }\end{array}$ & 1234566789 & 12234556789 & 1234566789 & N/A \\
\hline 14) & $\begin{array}{l}\text { Efficient interlibrary loan/document } \\
\text { delivery }\end{array}$ & 123456789 & 122344567889 & 1234556789 & N/A \\
\hline 15) & A comfortable and inviting location & 123456789 & 12334566789 & 123456789 & N/A \\
\hline 16) & $\begin{array}{l}\text { Employees who deal with users in a } \\
\text { caring fashion }\end{array}$ & 12234566789 & 122344567889 & 12234556789 & N/A \\
\hline 17) & $\begin{array}{l}\text { Modern equipment that lets me easily } \\
\text { access needed information }\end{array}$ & 123456789 & 12334566789 & 1223456789 & N/A \\
\hline 18) & Convenient service hours & 1233456789 & 122344567789 & 1233456789 & N/A \\
\hline 19) & $\begin{array}{l}\text { Employees who understand the needs } \\
\text { of their users }\end{array}$ & 12234556789 & 12234556789 & 12234566789 & N/A \\
\hline 20) & $\begin{array}{l}\text { Easy-to-use access tools that allow } \\
\text { me to find things on my own }\end{array}$ & 1223456789 & 12234556788 & 123456789 & N/A \\
\hline 21) & $\begin{array}{l}\text { A getaway for study, learning, or } \\
\text { research }\end{array}$ & 1233456789 & 1233456789 & 1223456789 & N/A \\
\hline 22) & Willingness to help users & 123456789 & 122344566789 & 1233456789 & N/A \\
\hline 23) & $\begin{array}{l}\text { Making information easily accessible } \\
\text { for independent use }\end{array}$ & 12234456789 & 12234566789 & 123456789 & N/A \\
\hline 24) & $\begin{array}{l}\text { Print and/or electronic journal } \\
\text { collections I require for my work }\end{array}$ & 1223456789 & 122344567889 & 122345567899 & N/A \\
\hline 25) & $\begin{array}{l}\text { Community space for group learning } \\
\text { and group study }\end{array}$ & 123456789 & 1233456789 & 1233456789 & N/A \\
\hline 26) & Modern equipment & 123456789 & 122345567889 & 12234566789 & N/A \\
\hline 27) & $\begin{array}{l}\text { Dependability in handling users' } \\
\text { service problems }\end{array}$ & 123456789 & 123456789 & 123456789 & N/A \\
\hline
\end{tabular}

Please indicate the degree to which you agree with the following statements:

\begin{tabular}{|c|c|c|c|c|c|c|c|c|}
\hline 28) & $\begin{array}{l}\text { The library helps me stay abreast of developments in my } \\
\text { field(s) of interest. }\end{array}$ & $\begin{array}{c}1 \\
\text { Strong }\end{array}$ & $\begin{array}{c}2 \\
\text { gly Dis }\end{array}$ & $\begin{array}{c}3 \\
\text { sagree }\end{array}$ & 4 & & & $\begin{array}{lcc}7 & 8 & 9 \\
\text { Strongly } & \text { Agree }\end{array}$ \\
\hline 29) & $\begin{array}{l}\text { The library aids my advancement in my academic } \\
\text { discipline. }\end{array}$ & $\begin{array}{c}1 \\
\text { Strong }\end{array}$ & $\begin{array}{c}2 \\
g l y \\
\text { Dis }\end{array}$ & $\begin{array}{l}3 \\
\text { sagree }\end{array}$ & & & & $\begin{array}{lcc}7 & 8 & 9 \\
\text { Strongly } & \text { Agree }\end{array}$ \\
\hline 30) & $\begin{array}{l}\text { The library enables me to be more efficient in my } \\
\text { academic pursuits. }\end{array}$ & $\begin{array}{c}1 \\
\text { Strong }\end{array}$ & $\begin{array}{l}2 \\
\text { gly Dis }\end{array}$ & $\begin{array}{l}3 \\
\text { sagree }\end{array}$ & & & & $\begin{array}{lcc}7 & 8 & 9 \\
\text { Strongly } & \text { Agree }\end{array}$ \\
\hline 1) & $\begin{array}{l}\text { The library helps me distinguish between trustwo } \\
\text { untrustworthy information. }\end{array}$ & $\begin{array}{c}1 \\
\text { Strong }\end{array}$ & $\begin{array}{c}2 \\
\text { gly Dis }\end{array}$ & $\begin{array}{l}3 \\
\text { sagree }\end{array}$ & & & & $\begin{array}{lcc}7 & 8 & 9 \\
\text { Strongly } & \text { Agree }\end{array}$ \\
\hline
\end{tabular}


PMM

9,3

\section{8} 32) The library provides me with the information skills I need
in my work or study.

33) In general, I am satisfied with the way in which I am treated at the library.

34) In general, I am satisfied with library support for my learning, research, and/or teaching needs.

35) How would you rate the overall quality of the service provided by the library?

\begin{tabular}{|c|c|c|c|c|c|c|c|c|}
\hline 1 & 2 & 3 & 4 & 5 & 6 & 7 & 8 & 9 \\
\hline \multicolumn{6}{|c|}{ Strongly Disagree } & \multicolumn{3}{|c|}{ Strongly Agree } \\
\hline 1 & 2 & 3 & 4 & 5 & 6 & 7 & 8 & 9 \\
\hline \multicolumn{6}{|c|}{ Strongly Disagree } & \multicolumn{3}{|c|}{ Strongly Agree } \\
\hline 1 & 2 & 3 & 4 & 5 & 6 & 7 & 8 & 9 \\
\hline \multicolumn{6}{|c|}{ Strongly Disagree } & \multicolumn{3}{|c|}{ Strongly Agree } \\
\hline 1 & 2 & 3 & 4 & 5 & 6 & 7 & 8 & 9 \\
\hline \multicolumn{6}{|c|}{ Extremely Poor } & \multicolumn{3}{|c|}{ Extremely Good } \\
\hline
\end{tabular}

Please indicate your library usage patterns:

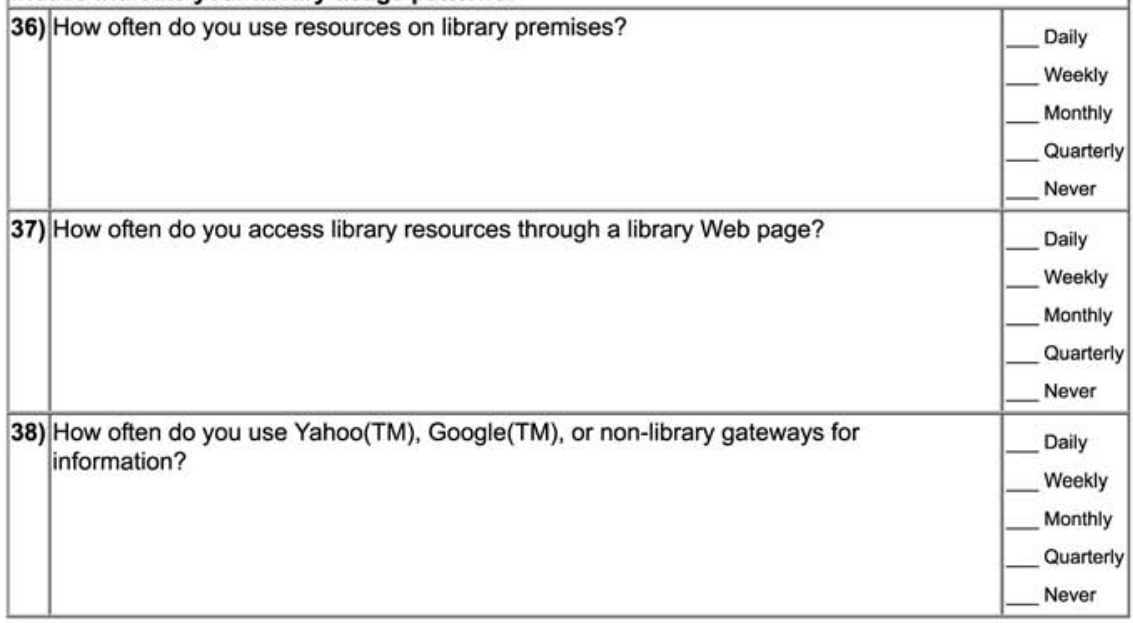

Please answer a few questions about yourself:

39) The library that you use most often:

\begin{tabular}{|c|c|}
\hline Ine inrary that you use most orten: & $\begin{array}{l}\text { _ Architecture and Planning Library } \\
\text { Benson Latin American Collection } \\
\text { Center for American History } \\
\text { C Chemistry Library } \\
\text { Classics Library } \\
\text { _ Engineering Library } \\
\text { Fine Arts Library } \\
\text { Geology Library } \\
\text { Harry Ransom Humanities Research Center } \\
\text { J.J. Pickle Research Campus } \\
\text { Life Science Library } \\
\text { Marine Science Library }\end{array}$ \\
\hline
\end{tabular}

Figure A1. 


\begin{tabular}{|c|c|c|}
\hline & & $\begin{array}{l}\text { _ Perry-Castañeda Library } \\
\text { Physics Mathematics Astronomy Library } \\
\text { Public Affairs Library } \\
\text { _ Tariton Law Library } \\
\text { Undergraduate Library }\end{array}$ \\
\hline 40) & Age: & $\begin{array}{l}\text { Under } 18 \\
-18-22 \\
-23-30 \\
-31-45 \\
-46-65 \\
\\
\text { Over } 65\end{array}$ \\
\hline 41) & Sex: & $\begin{array}{l}\text { Male } \\
\text { Female }\end{array}$ \\
\hline
\end{tabular}

Getting our priorities in order

42) Discipline:

Architecture
Business
Communication
Education
Engineering \& Computer Science
Fine Arts
Information
Law
Liberal Arts: Humanities
Liberal Arts: Social Sciences
Natural Sciences
Nursing
Other
Pharmacy
Public Affairs
Social Work

43) Position:

(Select the ONE option that best describes you.)

Undergraduate:

First year

_ Second year

_ Third year

__ Fourth year

_ Fifth year and above

_ Non-degree 


\section{PMM}

9,3

\section{0}

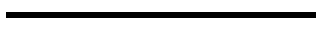

$$
\begin{aligned}
\text { Graduate: } & \text { _ Masters } \\
& \text { — }{ }^{\text {Doctoral }} \\
& \text { Non-degree or Undecided }
\end{aligned}
$$

Faculty: _ Adjunct Faculty

_ Assistant Professor

_ Associate Professor

_ Lecturer

_Professor

_ Other Academic Status

Library Staff:

_ Administrator

_ Manager, Head of Unit

Public Services

_ Systems

_ Technical Services

_ Other

Staff:

Research Staff

_ Other staff positions

44) Please enter any comments about library services in the box below:

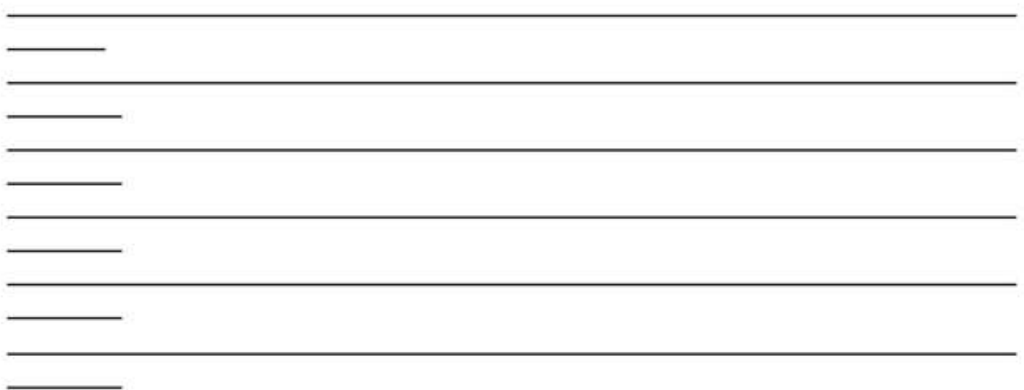

Figure A1.
Thank you for participating in this library service quality survey! 
Appendix 2

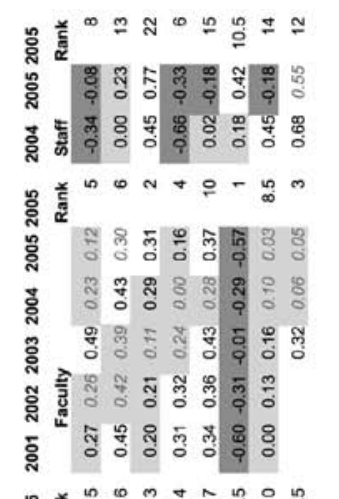

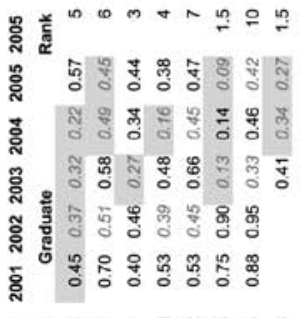

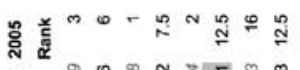

员 :

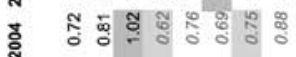

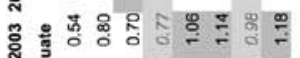

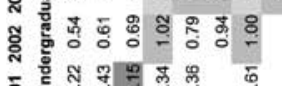

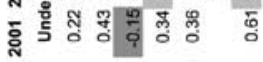

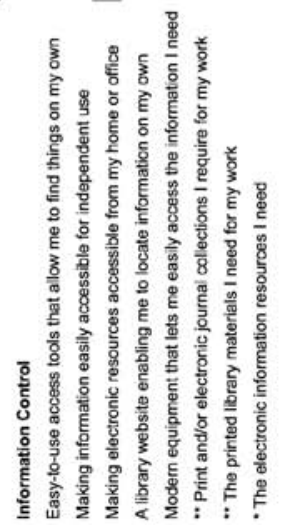

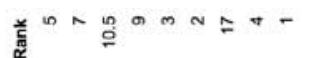

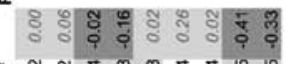

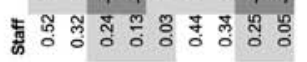

羊

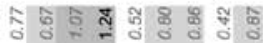

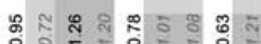

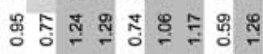

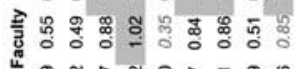

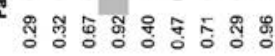

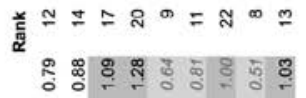

궁 \&

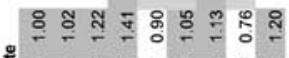

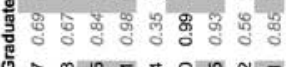

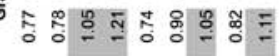

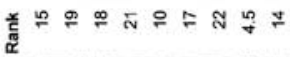

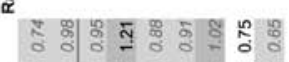

8웅

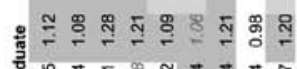

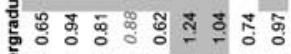

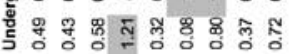

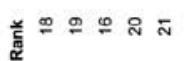

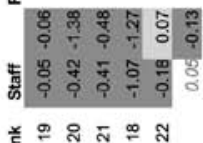

ํㅜㄹㅇㅗ ㄸำ

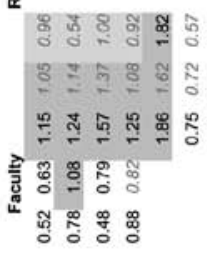

뜨모뜬

号芯芯芯

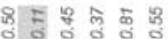

\% : ळ: 훙 : 융

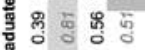

융: 융융

岛

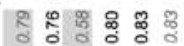

क5 항용 항 औै

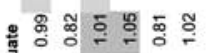

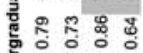

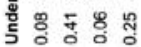

191
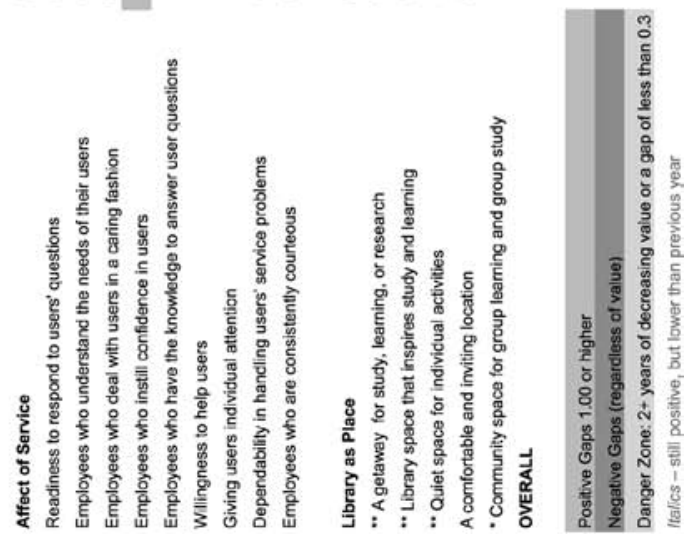

Figure A2. Adequacy gap by user group, 2001-2005

To purchase reprints of this article please e-mail: reprints@emeraldinsight.com

Or visit our web site for further details: www.emeraldinsight.com/reprints 